\title{
BORDERING ON ANTHROPOLOGY THE DIALECTICS OF A NATIONAL TRADITION IN MEXICO ${ }^{1}$
}

\author{
Claudio LomNITZ
}

RÉsumé : Cet article explore la production du savoir dans le cadre d'une « anthropologie nationale». Au Mexique s'est développée de façon précoce une des plus importantes anthropologies «nationales » du monde postcolonial; malgré son « succès », elle a toujours été hantée par l'absorption de ses principaux représentants dans l'appareil d'État et par un sentiment de discontinuité et d'isolement intellectuel. Quatre aspects de l'anthropologie mexicaine sont abordés dans le contexte historique où ils ont émergé : le rôle de l'anthropologie dans la construction d'une image de la nation (1850-1900); les stratégies d'intervention dans la modernisation et l'incorporation des populations indigènes et «attardées » (1880-1930); son rôle dans la régulation de l'orthodoxie du développement (1940-1968), puis dans la reformulation de l'image de la nation face à l'urbanisation massive (depuis 1968).

Mots-CLÉs : histoire de l'anthropologie, Mexique, nationalisme, développement, eugénisme, relativisme culturel, évolutionnisme.

ABSTRACT: This paper explores knowledge production within the framework of a "national anthropology». Mexico developed one of the earliest, largest and most successful "national » anthropologies of the postcolonial world, yet it has been haunted by constant absorption of its leading practitioners into the state apparatus and by a sense of intellectual discontinuity and isolation. The author explores four aspects of Mexican anthropology in the historical contexts in which they emerged: the role of the discipline in shaping a national image (1850-1900); its strategies of intervention in the modernization and "incorporation» of the indigenous and "backward" population (1880-1930); its role in the regulation of a development orthodoxy (1940-1968); and its role in the reformulation of a national image in the face of massive urbanization (1968-1980s).

KEYWORDS : history of anthropology, Mexico, nationalism, development, eugenics, cultural relativism, evolutionism.

1. I wish to thank Manuela Carneiro da Cunha, Fernando Escalante, James Fernandez, Friedrich Katz, Ev Meade, and Saul Thomas for their bibliographic suggestions. The usual disclaimers apply.

Revue de synthèse : $4^{\mathrm{e}}$ S. n ${ }^{\text {os }}$ 3-4, juil.-déc. 2000, p. 345-380. 
Zusammenfassung : In diesem Artikel geht es um die Entstehung von Wissen im Rahmen einer "nationalen Anthropologie ». In Mexiko ist sehr früh eine der wichtigsten «nationalen» Anthropologien der postkolonialen Zeit entstanden. Trotz ihrer Erfolge war sie immer dadurch behindert, daß ihre wichtigsten Vertreter im Staatsapparat beschäftigt waren; ferner krankte sie an einem Gefühl der Diskontinuität und der geistigen Isolierung. Im historischen Kontext ihres Auftretens werden vier Aspekte der mexikanischen Anthropologie untersucht : die Rolle der Anthropologie beim Aufbau eines Selbstbildnisses der Nation (1850-1900); die Strategien zur Mitwirkung bei der Modernisierung und der Eingliederung der einheimischen und der «zurückgebliebenen » Bevölkerungsgruppen (1880-1930); ihre Rolle bei der Definition einer Orthodoxie der Entwicklung (1940-1968); und schließlich ihre Rolle bei der Neuformulierung des Selbstbildnisses der Nation in Anbetracht der massiven Verstädterung (seit 1968).

STICHWÖRTER: Geschichte der Anthropologie, Mexiko, Nationalismus, Entwicklung, Eugenik, kultureller Relativismus, Evolutionismus.

Resumo : Este artigo explora a produção do saber em uma « antropologia nacional ». O México desenvolveu uma das primeiras, maiores e mais bem sucedidas antropologias «nacionais » do mundo pós-colonial. No entanto, ela tem sido atormentada pela absorção frequente de seus principais praticantes pelo aparelho de Estado e por um sentimento de descontinuidade e isolamento intelectual. $O$ autor examina quatros aspectos da antropologia mexicana em seus contextos históricos : o papel da disciplina na conformação de uma imagem nacional (1850-1900); as estratégias de intervenção na modernização $e$ «incorporação » das populações indígenas e " atrasadas » (1880-1930); sua função na regulação de uma ortodoxia do desenvolvimento (1940-1968); e seu desempenho na reformulação de uma imagem nacional face à urbanização em massa (desde 1968).

PaLAVRAS-Chaves: história da antropologia, México, nacionalismo, desenvolvimento, eugenia, relativismo cultural, evolucionismo.

Claudio LomnItz, né en 1957, a enseigné à l'Universidad metropolitana, El Colegio de México et à l'Universidad nacional autónoma de México. Il est actuellement professeur d'histoire et d'anthropologie à l'université de Chicago. Il est l'auteur de Evolución de una sociedad rural (1982), Exits from the labyrinth. Culture and ideology in Mexican national space (1992), et Modernidad indiana. Nueve ensayos sobre nación y mediación en México (1999). Son prochain ouvrage, Deep Mexico, silent Mexico est sous presse.

Adresse : Departement of History, University of Chicago, 1126 E.59th St., Chicago, IL, 60637, USA.

Courrier électronique : clomnitz@midway.uchicago.edu 
The current sense of crisis in American and European anthropology has been widely debated. Beginning with a series of criticisms of the connections between anthropology and imperialism in the 1970s, the critique of anthropology has moved into deeper epistemological terrain by questioning the narrative strategies used by ethnographers in order to establish scientific authority and their role in shaping « colonial» discourses of self and other. The field of anthropology in the United States and Europe is still reverberating from these discussions ${ }^{2}$. Less well known and understood, perhaps, is the quieter sense of unease and transformation in anthropological traditions that might be called «national anthropologies. » By «national anthropologies» I mean anthropological traditions that have been fostered by educational and cultural institutions for the development of studies of their own nation. In this paper I provide an historical interpretation of the gestation of the current malaise in one national tradition, Mexican anthropology ${ }^{3}$.

Peripheral nations with early dates of national independence, such as most Latin American countries, have been characterised by national traditions of anthropology that have evolved in tandem with European and American anthropology from their inception. The histories of these national anthropologies is still not very well known, in part because of the disjunction in the ways that anthropology is taught in the great metropolitan centers and in national anthropological traditions. Whereas in Britain, France or the United States anthropological histories are traced back in time within their own native traditions, «national anthropologies » often emphasize ties with great foreign scholars, thus placing themselves within a civilizing horizon whose vanguard is abroad. Commenting on this phenomenon, Darcy Ribeiro once said that his fellow Brazilian anthropologists were cavalos de santo (spirit mediums who spoke for their mentors in Europe or the United States). The works of anthropologists of «national traditions » thus often appear to be discontinuous with each other. To use a Mexican example, the influence of Franz Boas on Manuel Gamio and of Auguste Comte on the earlier Alfredo Chavero tends to mask the genealogical relations between Gamio and Chavero.

2. See the list of references at the end of the article, p. 377-379. Ortner, 1999, reviews recent books on the crisis in anthropology.

3. The sense that Mexican anthropology is undergoing a difficult transition is reflected in different ways in a number of works, see VÁZQUEZ LEÓN, 1987, or LOMNITZ, 1999, chap. IV. BARTRA, 1999, p. 43-48, offers Mexicans a choice between four « intellectual deaths », one of which can be summarized as « death by academy ». 
It is therefore not surprising that, although the existence of this class of « national anthropologies » is well known, it has not been sufficiently theorized. How does a discipline that owes so much to imperial expansion and «globalization », indeed a discipline that has often conceived of itself as the study of racial or cultural « others », thrive when its objects of study are the anthropologist's co-nationals? How are theories and methods developed in American or European anthropologies deployed in these national traditions? Is there a relationship between the current transformations of national anthropologies and «the crisis of anthropology » writ large?

The study of Mexican anthropology is instructive for the broader class of national anthropologies, since Mexico developed one of the earliest, most successful, and internationally influential national anthropologies ${ }^{4}$. The institutional infrastructure of Mexican anthropology is one of the world's largest and its political centrality within the country has been remarkable. This is linked both to the critical role that Mexico's archaeological heritage has played in Mexican nationalism and to anthropology's prominent role in shaping national development.

On the other hand, the sense of crisis in contemporary Mexican anthropology moves between two related concerns : the incorporation of anthropology and anthropologists into the workings of the state; and the isolation and lack of intellectual cohesiveness of the academy. The concern with the cooptation of Mexican anthropology in particular is a recurrent theme. In addition, there appears to be a disjunction between research, criticism and useful and positive social action (« relevance ») that has also been the subject of recent attention within greater anthropological traditions.

This paper claims that Mexican anthropology has reached a point in which it must transcend the limitations imposed by its historical vocation as a national anthropology. In order to lend credence to this normative claim, I explore the development of Mexican anthropology from the midnineteenth century to the present by focusing on four dynamic processes : the historical relationship between the observations of foreign scientific tra-

4. In 1973 Ralph Beals reviewed the field of Mexican anthropology and concluded that although it had had a relatively minor impact on anthropological theory, Mexican anthropology had played a critical role in the formation of a national conscience, and that the country had the third largest number of anthropology professionals, after Japan and the United States (cited in VÁZQUEZ LEón, 1987, p. 139). In fact, however, a number of national anthropologies, especially in Latin America, but also elsewhere, have turned to Mexico for inspiration during the 20th century. It should be noted, however, that Mexico has never been a "pure model » but, as in the case of Mexico itself, Mexican-inspired national anthropologies shaped networks of national institutions that were then connected especially to US, or occasionally to European missions : Cornell, Harvard, Chicago, Berkeley, Stanford, Unesco, and French cultural missions have been some of the institutional partners of these national institutions (for the case of Peru, see MARZAL, 1981). The influence of Mexican anthropology on the anthropology of the United States receives subtle treatment in Stern, 1999b, Tenorio Trillo, 1999, and Limón, 1998, chap. II. 
vellers and the production of a national image (materials used for this section range from the 1850s to the early 1900s); the relationship between evolutionary paradigms and the development of an anthropology applied to the management of a backward population and its incorporation to "national society » (materials from 1880s to 1920s); the consolidation of a developmental orthodoxy (materials from 1940s to 1960s); and the attempt to move from an anthropology dedicated to the study of «Indians » to an anthropology that was devoted to the study of social class (materials from 1970s to 1990s). I begin by contextualizing the current unease in Mexican anthropology, and move from there to the historical discussion.

1968/1995 : «CRITICISM HAS BEEN EXCHANGED FOR AN OFFICIAL POST ${ }^{5}$ »

The 1968 student movement produced a generational rupture in Mexican anthropology. Its manifesto carried the disdainful title of De eso que llaman antropología mexicana (Of that which is called Mexican anthropology, 1970), a book that was penned by a group of young professors of the National School of Anthropology who were playfully known in those days as «los siete magníficos» (the Magnificent Seven). The magníficos had had the daring to criticize that jewel on the crown of the Mexican Revolution that was indigenista anthropology.

By 1968 the identification of Mexican anthropology and official nationalism was at its summit. The new National Museum of Anthropology, which was widely praised as the world's finest, had been inaugurated in 1964, and the National School of Anthropology (ENAH) was housed on its upper floor. The institutional infrastructure of Mexican anthropology was firmly linked to the diverse practices of indigenismo, including bilingual education, rural and indigenous development programs throughout the country (centred on the Instituto Nacional Indigenista, INI), and a vast research and conservation apparatus, housed mainly in the Instituto Nacional de Antropología e Historia (INAH). Mexican anthropology had provided Mexico with the theoretical and empirical materials that were used to shape a modernist aesthetics, embodied in the design of buildings such as the National Museum of Anthropology or the new campus of the National University. It was charged with the task of forging Mexican citizenship both by « indigenizing » modernity and by modernizing the Indians, thus uniting all Mexicans in one mestizo community. In Mexico this is what was called indigenismo.

5. Reference is to WARMAN, 1970, p. 34 : «Criticism had been substituted by a [official] post (un nombramiento). [...] Anthropology had been rewarded with lifelong benefits in the Instituto de Seguridad Social y Servicios a los Trabajadores del Estado. » 
According to the magnificos, then, Mexican anthropology had placed itself squarely in the service of the state, and so had abdicated of both its critical vocation and its moral obligation to side with the popular classes. The generation of 1968 complained that Mexican indigenismo had as its central goal the incorporation of the Indian to the dominant system, a system that was called «national» and «modern» by the indigenistas, but that was better conceived of as «capitalist» and «dependent». Mexican anthropology was described as an orchid in the hot-house of Mexico's authoritarian state, coopted and entirely saturated by its needs and those of foreign capital.

Moreover, the legitimate actions of early indigenistas and their ties to the Mexican revolution had been exhausted. In the words one of the magnificos, Guillermo Bonfil :

« Today we can contrast the reality of Mexican society with the ideals of the Revolution and establish the distance between the two [...] It would be difficult to doubt that in these days we can no longer do justice to the future by maintaining the same programs that were revolutionary 60 years ago. Those programs have either run their course or else they have been shown to be ineffective, useless or, worse yet, they have produced historically negative results ${ }^{6}$.»

Thus, the authors of De eso que llaman antropología mexicana called for Mexican anthropologists to keep their distance from the state. They should steer clear of a policy (indigenismo) that had the incorporation of the Indian to «national society » as its principal aim. « National society », noted Arturo Warman, was always an undefined category that simply stood in for what Rodolfo Stavenhagen and Pablo González Casanova had called « internal colonialism » as early as 1963. The aim of Mexican indigenismo had been the incorporation of the Indian to the capitalist system of exploitation, and in so doing it had abandoned the scientific and critical potential of the discipline ${ }^{7}$.

Not surprisingly, tensions grew strong in the National School of Anthropology, and they culminated in the expulsion of Bonfil from the School by director Ignacio Bernal. The fact that a number of indigenistas remained loyal to the government during and after the 1968 movement was seen by the sesentayocheros as a final moment of abjection, and it marked the end

6. Bonfil, 1970, p. 42.

7. Scientific research and critical discourse were subsequently (and erroneously, I think) counterposed to the practice of indigenismo, see Andres Medina and Carlos García Mora, cited in Méndez Lavielle, 1987, p. 362 : « The state doesn't care about the development of anthropology as a science that is capable of analyzing reality and modifying it deeply. At most it is interested in it as a technique to train restorers of ruins and taxidermists of languages and customs. However, it finds that the schools of anthropology [...] are centers where students gather and study reality in order to transform it, that they fight for democratic liberties and that they maintain a militant attitude on the side of the oppressed. » 
of that school's dominance in Mexican academic settings. Twenty years later, however, Warman, who was the most famous of the magnificos and author of a number of books that were critical of Mexico's agrarian policies, accepted the post of director of the Instituto Nacional Indigenista, and later that of secretary of agrarian reform under president Carlos Salinas. From this position Warman conducted the government's agrarian policies, which were directed precisely at incorporating Mexican peasants to forms of production geared towards the market. Thus the cooptation of the anthropological establishment seemed to repeat itself, complete with its own moment of drama : in March 1995, Mexico City papers reported that Warman was charged with pleading to former president Salinas on behalf of president Ernesto Zedillo to put an end to a one day hunger strike ${ }^{8}$.

My contention is that the vision of anthropology's history repeating itself in a never-ending cycle of state incorporation is misleading. In this essay I seek to elucidate the origins, historical evolution and current exhaustion of the Mexican tradition as a confined, national, anthropology.

Shaping an image of national stability, of collective serenity, security and seriousness of purpose has never been an easy task in Mexico. It was absolutely impossible to accomplish in the decades following independence (1821), when governments had to operate with unstable and insufficient revenue, a foreign debt that was difficult to pay, constant internal revolutions, a highly deficient system of transportation, and frequent foreign invasions. The image of Mexico abroad, an image that had been so important to Mexican politicians and intellectuals even before the baron Alexander von Humboldt published his positive accounts of New Spain, had turned very contrary indeed. Naturalists and ethnographers who followed Humboldt's steps took a decidedly negative view of Mexico's present and a pessimistic view of its future ${ }^{9}$.

A useful point of entry for understanding the labors of early Mexican anthropologists is a discussion of Edward B. Tylor's travel book on Mexico, which recapitulates the adventures and impressions that he and the collector Henry Christy had on their trip to Mexico in 1856. To my knowledge, this book has never been published in Spanish, and it is not widely

8. Proceso, 1995.

9. Foreign negative images of New Spain were the catalyst for some of the most distinguished eighteenth-century historical and anthropological writings by Mexican Creoles. For a discussion, see Gerbi, 1973. 
known or read in Mexico. This is odd at first glance, given Mexico's legitimate claim to have been the muse that inspired the discipline that in Oxford was at times referred to as «Tylor's science ${ }^{10}$ ». The lack of attention to Tylor's Mexican connection seems even stranger given the need that countries like Mexico have had to remind the world that they have not been absent in the process of shaping the course of Western civilization ${ }^{11}$.

Mexico's failure to appropriate Tylor's Anáhuac seems less perplexing when we actually read the book. Tylor described a Mexico whose presidency had changed hands once every eight months for the past ten years, a country whose fertile coastal regions were badly depopulated, and whose well inhabited highlands were bandit - infested and difficult to travel. Mexico was also a country that was sharply divided by race, where the whites and half-castes were hated by the Indians whom they exploited (see figure 1, p. 353).

Tylor's first vista of Mexico is the port of Sisal, in the Yucatan, and it gets the Mexican reader off to an uneasy start, suggesting the fragility of Mexico as a polity and its lack of cohesiveness as a nation :

«One possible article of export we examined as closely as opportunity would allow, namely, the Indian inhabitants. There they are, in every respect the right article for trade : brown-skinned, incapable of defending themselves, strong, healthy, and industrious; and the creeks and mangrove swamps of Cuba only three days' sail off. The plantations and mines that want one hundred thousand men to bring them into full work, and swallow aborigines, Chinese, and negroes indifferently - anything that has a dark skin, and can be made to work - would take these Yucatecos in any quantity, and pay well for them ${ }^{12}$.»

Tylor's first impression was a disturbing reminder of the fragility of the links between Mexico's people and its territory. His observation revealed what is still today something of a dirty secret, which is that Mayas were indeed being sold as slaves in Cuba at the time. But if Tylor's first impressions were unsettling, Mexican nationalists would find little solace in his conclusions :

« That [Mexico's] total absorption [to the United States] must come, sooner or later, we can hardly doubt. The chief difficulty seems to be that the American constitution will not exactly suit the case. The Republic laid down the right of each citizen to his share in the government of the country as a universal law

10. British Museum, 1965, p. 1, also calls the collector Henry Christy, who led Tylor to Mexico, the "godfather of anthropology ».

11. Unveiling these connections is the painstaking subject of much of the scholarship of the recent decades, from Latin American « dependency theory » to Edward Said's Culture and imperialism, but it has also been a constant concern since the late nineteenth century.

12. TyLOR, 1861, p. 16-17. 


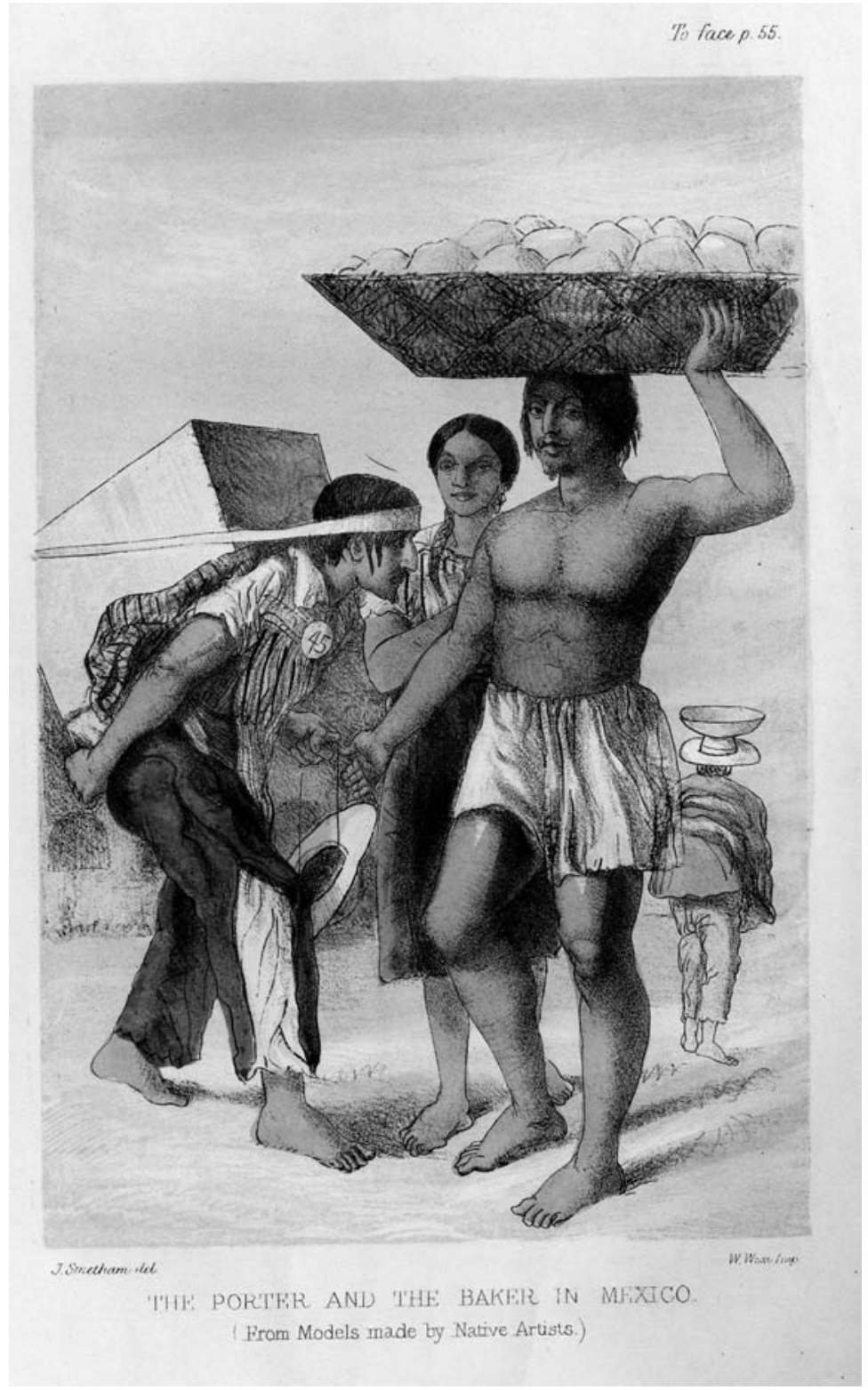

Fig. 1. — «Porter and Baker in Mexico», in TYLOR, 1861, p. 54. 
[...] making, it is true, some slight exceptions with regard to red and black men. The Mexicans, or at least the white and half-caste Mexicans, will be a difficulty. Their claims to citizenship are unquestionable, if Mexico were made a State of the Union; and, as everybody knows, they are totally incapable of governing themselves [...] Moreover, it is certain that American citizens would never allow even the whitest of the Mexicans to be placed on a footing of equality with themselves. Supposing these difficulties got over by a Protectorate, an armed occupation, or some similar contrivance, Mexico will undergo a great change. There will be roads and even rail-roads, some security for life and property, liberty of opinion, a flourishing commerce, a rapidly increasing population, and a variety of good things. Every intelligent Mexican must wish for an event so greatly to the advantage of his country [...] As for ourselves individually, we may be excused for cherishing a lurking kindness for the quaint, picturesque manners and customs of Mexico, as yet un-Americanized; and for rejoicing that it was our fortune to travel there before the coming change, when its most curious peculiarities and its very language must yield before foreign influence ${ }^{13}$. »

Tylor's Mexicans were, in most respects, an unenlightened people. Mexican schooling was dominated by an obscurantist and corrupt Church. The legal system gave no protection to ordinary citizens, who were at a structural disadvantage with respect to soldiers and priests. The population avoided paying taxes because the government was ineffective. The country as a whole was in the hands of gamblers and adventurers, and Mexican jails offered no prospect of reforming prisoners.

Finally, ethnologists and historians of the period must have been struck by the Mexican government's incapacity to control the connections between the nation's past and its future, a fact that is demonstrated by Tylor and Christy's activities as collectors of historical trophies, but even more potently by Tylor's remarkable description of Mexico's national museum (see figure 2, p. 355) :

«The lower story had been turned into a barrack by the Government, there being a want of quarters for the soldiers. As the ground-floor under the cloisters is used for the heavier pieces of sculpture, the scene was somewhat curious. The soldiers had laid several of the smaller idols down on their faces, and were sitting on the comfortable seat on the small of their backs, busy playing at cards. An enterprising soldier had built up a hutch with idols and sculptured stones against the statue of the great war-goddess Teoyaomiqui herself, and kept rabbits there. The state which the whole place was in when thus left to the tender mercies of a Mexican regiment may be imagined by any one who knows what a dirty and destructive animal a Mexican soldier is ${ }^{14}$. »

13. TYLOR, 1861 , p. $329-330$.

14. TYLOR, 1861, p. 222. On the subject of the government's care for its antiquities, TYLOR, 1861 , p. 275 , tells how he and Henry Christy literally created markets for antiquities : « At the top of the pyramid [of Cholula] we held a market, and got some curious things, all of small 


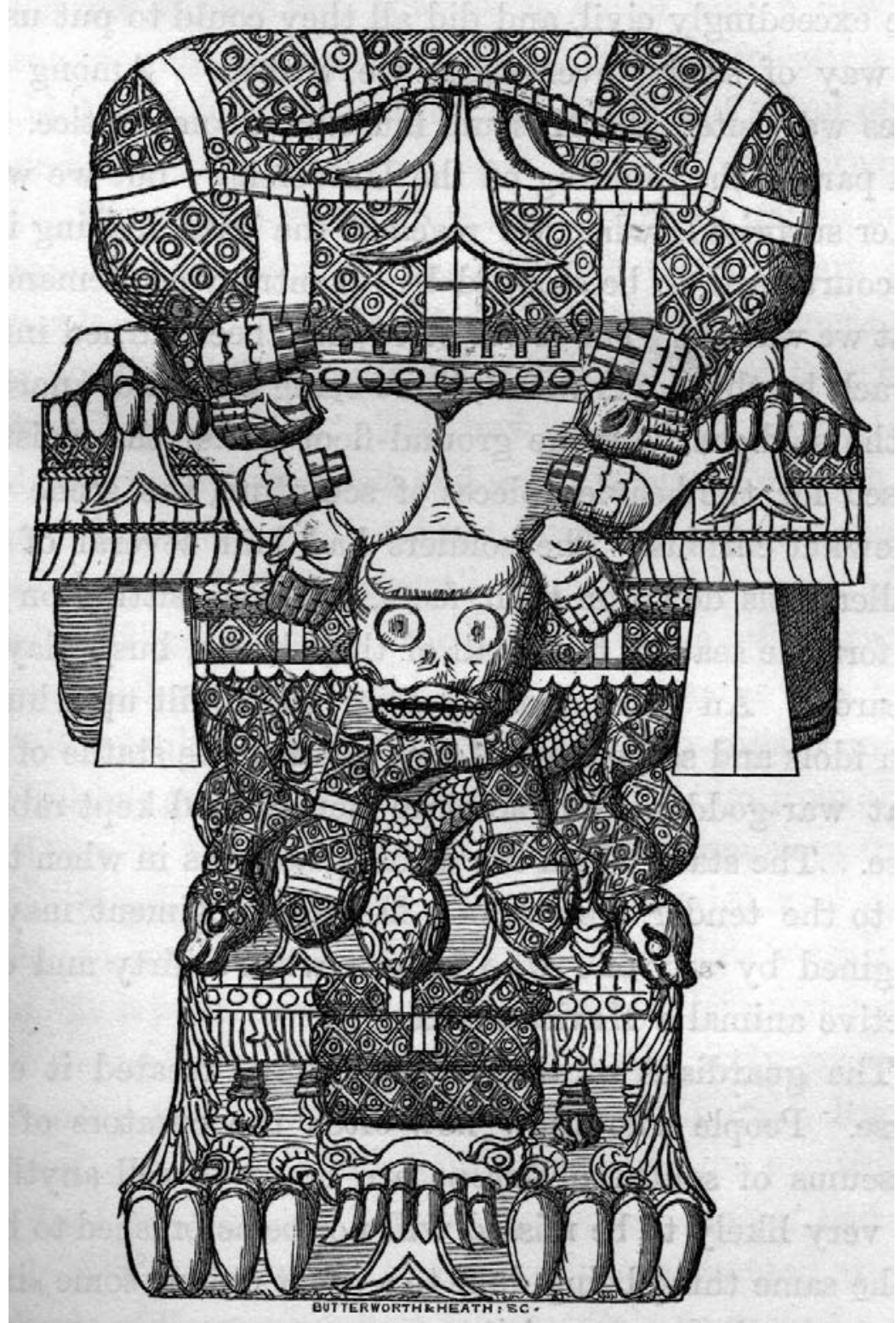

Fig. 2. - "Goddess Teoyaomiqui, currently known as Coatlicue », in TYLOR, 1861, p. 221. 
Mexican anthropology has had multiple births : the writings of the sixteenth century friars, and especially of Bernardino de Sahagún, are frequently cited, but so are those of creole patriots and antiquarians writing in the seventeenth and eighteenth centuries, or the foundation of the International School of American Archaeology and Ethnology in 1911 by Boas, and the creation of the first Department of Anthropology by his student, Gamio, in $1917^{15}$. Anáhuac represents an unacknowledged, but no less important point of origin, for Tylor's first book was the sort of travel narrative that anthropologists, including Tylor himself, tried to trump with the scientific discipline of anthropology, retaining the sense of discovery and of daring of the genre while reaching for systematization and emotional distance $^{16}$. For Mexican intellectuals, however, Anáhuac pointed to the unspeakable but omnipresent nightmare of racial dismemberment, national disintegration, and the shameful profanation of the nation's grandeur by the state itself. Anáhuac, in other words, is a work that both British and Mexican anthropologists would write against. As in a Freudian dream, the primal scene has been carefully hidden, but the development of anthropology in Mexico (and, indeed, in Britain) was to a significant degree shaped by the negative imprint of this book and others like it.

After the publication of Anáhuac, things in Mexico took a different turn than the one that Tylor had envisioned. Instead of being invaded by the United States, Mexico was occupied by France, who made the best of the American Civil War, by regaining a foothold in the continent ${ }^{17}$. And although Tylor was not entirely wrong in thinking that a number of Mexicans would welcome the intervention of a great power, civil strife and resistance against the French proved stronger than he had anticipated, and the turn of world events frowned upon Mexico's second empire. After its «second independence », however, Mexico had yet to show that it was a politically viable country, a country that was capable of attracting foreign investors, a country that could embrace progress.

One important move in this direction was a book written by Vicente Riva Palacio and Manuel Payno, both of whom would later lead the manufacture of a new history of Mexico ${ }^{18}$. El Libro rojo (1870) was amongst the first of a series of lavishly printed and illustrated volumes of the final third

size however. » Christy's ethnographic collection became the most important of its time, and over half of its registered pieces were Mexican, see British Museum, 1965, p. 11.

15. For standard recapitulations of this vision, see WARMAN, 1970, and Lomnitz, 1999, chap. IV.

16. Pratt, 1992.

17. In 1862 Napoleon III sent troops to occupy Mexico and install Maximilian of Hapsburg as emperor. French troops were finally defeated and Maximilian executed in 1867.

18. Tenorio Trillo, 1996, is the path-breaking book on this subject. 
of the 19th century. It is a brief history of civil violence in Mexico, told by way of an illustrated look at executions and assassinations, much as if it were a book of saints. El Libro rojo is remarkable for its ecumenical reproach of civil violence. Illustrated pages are dedicated equally to Cuauhtemoc and to Xicotencatl (Indian kings who fought on opposite sides during the conquest), to conquistador Pedro de Alvarado and to the Aztec emperor Moctezuma, to Jews who were burned by the inquisition and to priests who were massacred by Indians, to marooned African slaves and to a Spanish archbishop. Even more remarkably, the pantheon of martyrs includes heroes on alternate sides of Mexico's civil struggles of the 19th century, father Miguel Hidalgo and general Agustin de Iturbide, liberals and conservatives. Even Maximilian of Hapsburg, who had been executed by the still reigning president, Benito Juárez, was given equal treatment.

El Libro rojo sought to shape a unified Mexico, by acknowledging a shared history of suffering. Ideologically, this was the course that was later taken under general Porfirio Diaz (1884-1910) ${ }^{19}$. The work of the Red Book was, firstly, directed to unifying elites, a fact reflected in the book's guiding interest in state executions, rather than in the anonymous dead produced by civil strife or exploitation. The unification of elites involved taming the nation's war-torn past and projecting this freshly re-built past into the present in order to shape a modernizing frontier. It is therefore not surprising that the pacification and stabilization of the country that followed slowly after the French Intervention required the services of an illustrated elite, that came to be known as the «científicos ", in order to shape Mexico's image.

This has been the subject of detailed work by Mauricio Tenorio Trillo, in his book on Mexico in the Worlds Fairs and elsewhere. I shall illustrate the kind of work that was accomplished by this intelligentsia by referring to a book that was published in English by Justus Sierra and a team of illustrious científicos in 1900, Mexico. Its social evolution. This work is of special interest not only because Sierra was such a prominent and influential figure in Mexican culture and education, but also because it was printed in English, and its lavishly produced illustrations seem to provide an answer to the negative comments and images of Mexico offered by Tylor and other travelers point by point.

The fundamental strategy followed by Sierra's team was to make Mexico's evolution comprehensible and parallel to that of Britain or the United States (that is, to an English-reading audience). Thus, the names of authors and historical characters were anglicized, from «Jane Agnes de la Cruz » to «William Prieto », and parallels between Mexico's evolution and

19. Widdifield, 1996, p. 61-64; Tenorio Trillo, 1996, p. 30, et 1999. 
that of the civilized world were explicitly or implicitly established. Carlos («Charles ») de Sigüenza y Góngora is placed alongside Sir Isaac Newton, Río de la Loza is followed shortly by Auguste Comte, and photographs of museums, hospitals and courthouses built in Victorian or the latest Parisian styles were displayed page after page. This mimetic strategy was common among Mexico's elite literary and scientific circles of the Belle Époque, but it is taken up in a punctual manner by Sierra, who endeavors to show that each of the hallmarks of progress exists in Mexico.

Tylor complained of the state of abandon of Mexican education and its subordination to a retrograde Church, Sierra provided discussions of the development of Mexican positive science. Tylor smiled ironically at the lack of attention that was given to Mexico's history and patrimony, Sierra shows the National Museum of Anthropology and the ways in which Mexico's once conflict-torn races have been neatly studied and organized in it (see figure 3, p. 359). Finally, Tylor noted the arbitrariness of Mexico's government, the lack of justice, and of institutions of social reform. Sierra shows the rapid and impressive development of courts of law, of councils, hospitals, schools, museums and prisons. In short, while Tylor spoke of a country that had been ravaged by revolution, Sierra's book spoke of evolution.

In this dialogue between Tylor's and Sierra's books one can catch a glimpse of the central role that anthropology would have in Mexico's history. To simplify matters, one could say that the international character of anthropology has the capacity to destabilize nationalist images of Mexico. Mexico's national anthropology has worked hard to curb these tendencies by producing images of the parallels between Mexico's development and that of the nations that produce anthropologists who travel.

\section{SHAPING NARRATIVES OF INTERNAL HIERARCHY, ORGANIZING GOVERNMENTAL INTERVENTION IN THE MODERNIZING PROCESS}

In addition to shaping and defending its national image, Mexico's anthropology had, from the beginning, a role to play in the criticism and organization of internal hierarchies.

Even before the rise of any solid institutional framework for the development of Mexican anthropology, discussions and writings on race and on the historical origins of Mexico's peoples were constantly deployed in order to orient strategies of government. The Boletín de la Sociedad Mexicana de Geografía y Estadística (BSMGE), Mexico's oldest scientific periodical, founded in 1839, has many examples of this. Statistical and population reports drafted in the 1850 s and 1860 s often carried sections on race, for 


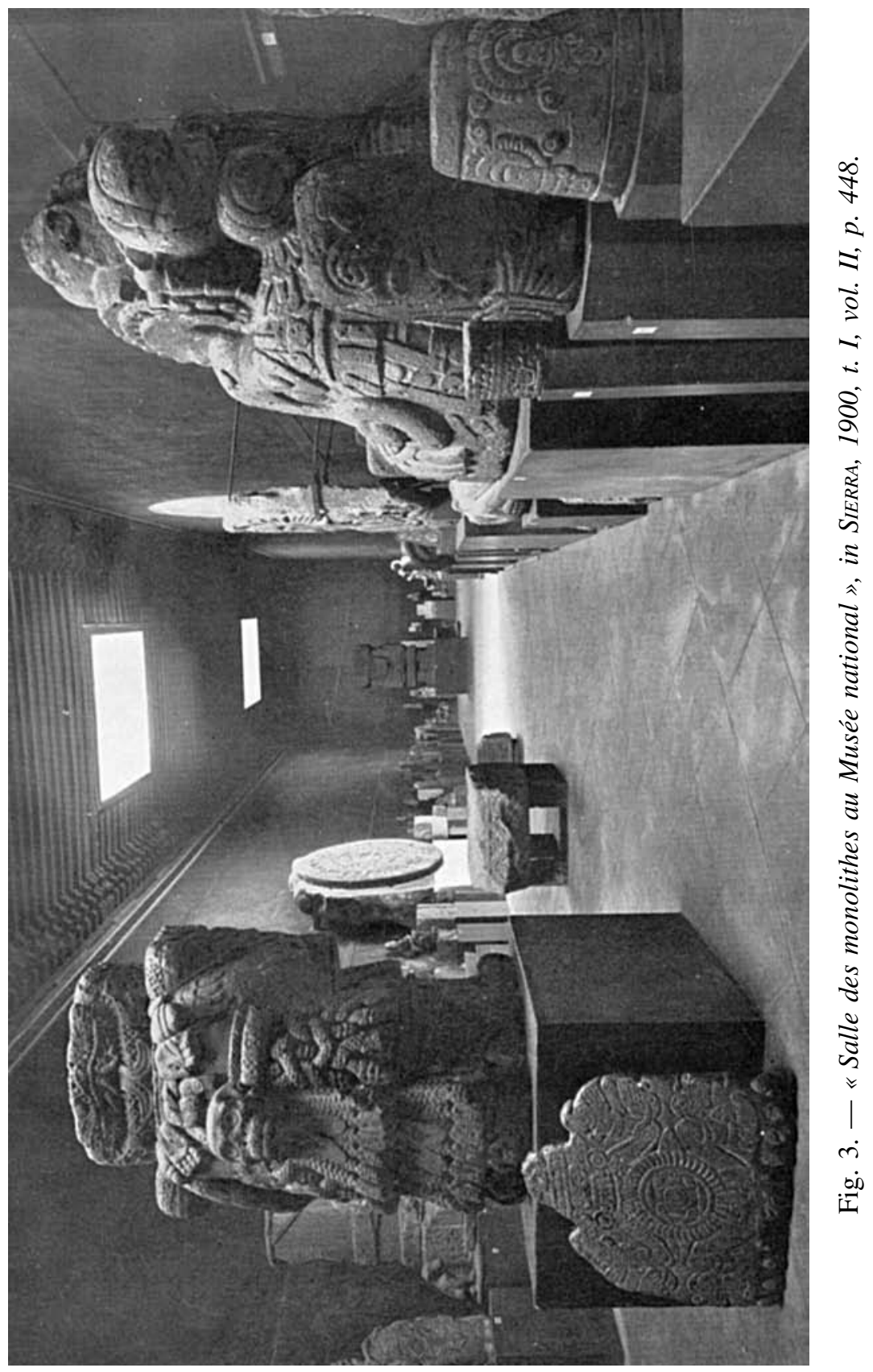


instance. Thus, Juan Estrada in his report on the Prefectura del Centro of the State of Guerrero says that:

«Of the 25,166 souls in the prefecture, 20,000 are Indians. However, what is painful is that the remaining 5,000 are not educated, nor do they refrain from uniting with the Indians in their designs to exterminate the Hispano-Mexican $\operatorname{race}^{20} . »$

In the same period (1845), the Constitutional Assembly of the Department of Queretaro gives a more nuanced account of the racial question in its state :

«The wise regulatory policy of our government has proscribed for ever the odious distinctions between whites, blacks, bronzed and mixed races. We no longer have anything but free Mexicans, with no differences amongst them except those imposed by aptitude and merit in order to opt for the various destinies of the republic ${ }^{21}$. »

However, the authors go on :

«We would abstain from making this sort of classification [i.e., "racial classification"] were it not true that just as politics prefers to treat citizens as essential parts of the nation, so does economics prefer to consider their specific condition, not in order to worsen it but, on the contrary, to seek its improvement. Without a practical knowledge of the peoples (los pueblos) we cannot improve their civilization, their morality, their wealth, nor the wants that affect them ${ }^{22}$.»

The congress then proceeds to discuss the qualities and deficiencies not only of Queretaro's three main races (Indians, mixed-bloods, and creoles), but also important distinctions within the creole race according to levels of education. Thus, while the highest class of creoles is circumspect, controlled and similar to the ancient Spartans, the classes beneath them can be fractious.

Statistics supplied by the state of Yucatán for the year 1853 include detailed discussions of the relationship between race and criminality, showing that Indians are less likely to participate in violent crimes than castas or creoles, because the Indian race is belittled (apocada) either naturally or due to degeneration. Correspondingly, Indians indulge in petty theft, and they do so systematically :

20. Estrada, 1852, p. 74.

21. BSMGE, 1852 , p. 232 . In a footnote the Congress of Querétaro contrasts its enlightened view of race with the " horrible anomaly » of slavery in the United States, see ibid.

22. BSMGE, 1852, p. 232. 
«The Indian steals. More than anything he is a thief, and this he is without exception, and in as many ways as he can. However, due to their petty nature, these thefts escape the action of justice, and so are not recorded in the annals of crime $^{23}$. »

Statistics from the department of Soconusco in Chiapas in the same period divided local races into Ladinos, Indians, Blacks and Lacandones ${ }^{24}$.

It is clear from these reports that there was not a fixed national system of racial composition, but that the races, and even to some extent the specificities of their character, varied substantially by region. Even Tylor's classification of Mexican races reflects this, for although he foregrounds the relationship between Indians, half-castes and Spanish-Mexicans, Tylor also mentions the black population in the Veracruz region, and divides Mexican Indians into three types : brown Indians, red Indians, and blue Indians ${ }^{25}$.

One of the principal tasks of anthropology as it began to develop in the 1880s was to put order into these regional hierarchies of race and to tie them into a vision of national evolution of the sort that was so successfully displayed in Sierra's Mexico. Its social evolution. A key strategy for this can be found in Chavero's work on pre-Columbian history in Mexico a través de los siglos (1888), a work that develops an evolutionary scheme for pre-Columbian history that implicitly organizes hierarchical relations between the races in the present.

Chavero describes Mexico's pre-Columbian past as if it had been lying dormant, waiting below the earth for his patriotic generation to bring it back to life. Throughout the ravages of colonial destruction and the revolutions of the 19th century, the colossal Mexican past slept under a blanket of soil :

«But our ancient history had been saved, and all that could have perished in oblivion shall today rise to our hands. Even if these hands be guided more by daring than by knowledge, they are also moved by love of country, a love that embraces the desire to preserve old memories and ancient deeds just as the great hall of a walled castle keeps the portraits of each of its lords, the sword of the conquistador and the lute of the noble lady ${ }^{26}$.»

After claiming the possession of the noble treasures of the past for his country, Chavero proposed an evolutionary story for pre-Columbian

23. Sociedad..., 1852, p. 294.

24. PINEDA, 1852.

25. These so-called «blue Indians, » known in Mexico at the time as pintos, were the troops of general Juan Alvarez that had overrun Mexico City shortly before Tylor's visit, and they were «blue » because many of them had a skin disease that erases pigment in large patches.

26. Chavero, 1888, p. iv. 
Mexico. This story had blacks as the initial inhabitants. However, these blacks were weaker and less well suited to most of Mexico's environment than the race that expelled them from all but the torrid tropical zones : the Otomís. For Chavero, then, it is the Otomís who can be truly called Mexico's first inhabitants. However, the Otomís were not much better than the blacks : they were a population of troglodites who spoke a monosyllabic tongue ${ }^{27}$, a people that was still in humanity's infancy :

«Life in those days could be nothing but the struggle for sustenance. Families were formed only by animal instinct. Intelligence was limited inside the compressed crania of those savages [...] And just as nothing linked them to heaven or to an eternal god, so too did they lack any ties to the earth, there was no fatherland (patria) for them ${ }^{28}$. »

Despite these unpromising beginings, the inferiority of the Otomís did not deeply scar the nation's pride. Instead, it actually proved useful to understanding contemporary racial hierarchies, for the Otomís initiated an evolutionary movement that culminated with the magnificent Nahoas, a race whose apparition was, according to Chavero, contemporaneous with that of the great civilizations of Egypt, India and China. Moreover, the Otomís offer a valuable perspective from which to comprehend the condition of the Indians during Chavero's present, for the Otomís were the Indians' Indians, they were the conquered peoples of those who were later, in their turn, conquered. Because of this they allow the Mexican to relativize the Spanish conquest and to diminish its weight in national history :

«But did these first peoples acquire any culture? We are not surprised to find them degraded and almost brutish in the historical period. They were torn apart by invasions without receiving new life-blood (savia) from the conquerors, and inferior peoples descend and perish when they come into contact with more advanced people. We would be wrong to judge the state of the ancient kingdom of Mexico before the conquest on the basis of our present-day Indians ${ }^{29}$. »

In one stroke Chavero has established both the grandeur of the Mexican past and the key to comprehend its fall, and so has put aside the painful

27. Chavero, 1888 , p. 65 : «Language is of great value for explaining ethnographic relations. Otomí is a language of an essentially primitive character. The Mexicans call it otomitl, but its true name is hiáhué. All of the circumstances of this language reflect the poverty of expression of a people that is contemporaneous to humanity's infancy. » In his views of indigenous linguistics, Chavero follows the work of Pimentel, 1860a, p. 370, who argues that monosyllabic languages, such as Chinese and Otomí, have no grammar and are the most primitive. In their disdain for Otomí and Chinese, PIMENTEL, $1860 \mathrm{~b}$ and Chavero were following racist trends in European romantic linguistics. See Bernal, 1987, chap. v, esp. p. 237-238. For a discussion of scientific stereotypes of Mexican Indians, see Buffington, 2000, p. 149-155.

28. Chavero, 1888, p. 69.

29. Chavero, 1888, p. 67. 
image that foreigners still projected of Mexico in Chavero's day. Mexico's pre-history and its present thus mapped on to each other; they completed one another. The images of the Negro, Otomí, and early Nahoa races (see figures 4, 5, 6, p. 364) illustrate this point : whereas Chavero used archaeological pieces to portray the early Negro and Nahoa races, he relied on a drawing of a contemporary «Indian type » to portray the ancient Otomí.

The contemporary «degenerate» Indian type maps onto and indeed substitutes for the missing image of the early and un-evolved Otomí, just as the ancient grandeur of the Nahoa completes the image of Mexico's future as it is being shaped by its científico elite.

Moreover, there is a striking similarity between Chavero's description of the degraded Otomís and contemporary descriptions by foreigners of the Mexican Indian. For example, the US historian Hubert Bancroft wrote a diary of his travels to Mexico at the time when Mexico a través de los siglos was under preparation, and he makes the following comment regarding the pervasive fears of US annexation amongst Mexicans :

«But what the United States wants of Mexico, what benefit would accrue from adding more territory, what the nation has to gain from it I cannot fathom. [...] If there were nothing else in the way, the character of the Mexican people would be objection enough. The people are not the nation here as with us; the politicians are absolute. There is no middle class, but only the high and the low, and the low are very low indeed, poor, ignorant, servile and debased, and with neither the heart or the hope ever to attempt to better their condition. I have traveled in Europe and elsewhere, but never have I before witnessed such squalid misery and so much of it. Sit at the door of your hotel, and you will see pass by as in some hellish panorama the withered, the deformed, the lame and the blind, deep in the humility of debasement, half hidden in their dingy, dirty raiment as if the light of heaven and the eyes of man were equally painful to them, hunchbacks and dwarfs, little filthy mothers with little filthy babies, grizzly gray headed men and women bent double and hobbling on canes and crutches $^{30}$.»

In the face of such devastating impressions on travelers, Chavero and his generation strove to make Mexico presentable to the patriot, to make it defendable vis-à-vis the foreigner, and especially to attract foreign allies. The success of this great concerted effort of the Porfirian intellectual elite has been discussed by Tenorio Trillo, who calls the team of Mexican intellectuals and politicians who pulled it off « wizards ». This is perhaps not an exaggeration. Fernando Escalante has reminded us that during most of the 19th century, Veracruz, a town that was so plague-ridden that it was known

30. BANCROFT, 1883, p. 18-19. 


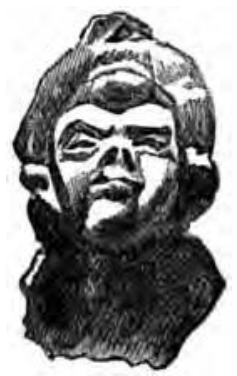

Fig. 4. — «Tipo otomí », in Chavero, 1888, vol. I, p. 66.

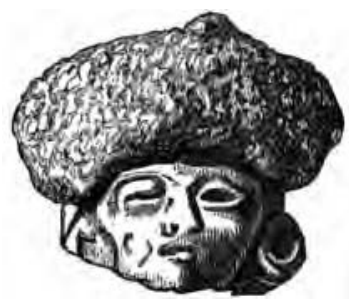

Fig. 5. — « Cabecita de Teotihuacán », in CHAVERo, 1888, vol. I, p. 69.

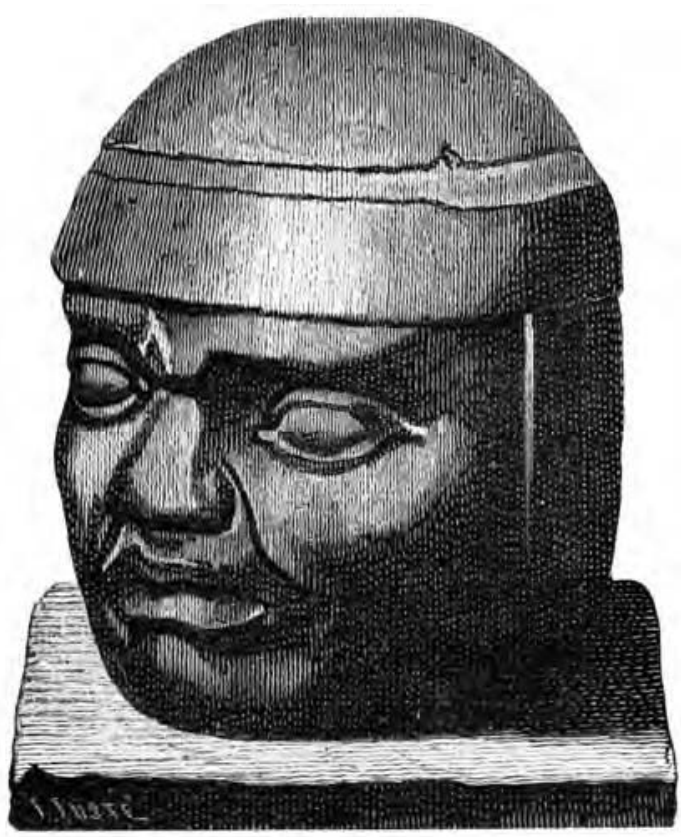

Fig. 6. - «Cabeza gigantesca de Hueyapan », in Chavero, 1888, vol. I, p. 63. 
as «the city of death », was nevertheless the favorite city of the creoles, because it was the best way to get out of the country.

The role of Chavero and other early anthropologists was to suggest a certain isomorphism between the past and the present. By creating a single racial narrative for the whole country, these anthropologists could shape the internal frontiers of modernization, while upholding a teleology that made progress and evolution an integral aspect of Mexican civilization. Moreover, this strategy involved using history to make moral assertions about the present, which was an immensely popular activity in Mexico that had significant grassroots appeal ${ }^{31}$.

The generation of Porfirian anthropologists would use this evolutionary theory as a frame for shaping Mexico's image, but revolutionary anthropologists would use it to intervene directly in native communities. The key figure in this development was Gamio, who was so successful that he is generally considered the "father» of Mexican anthropology. Because Gamio's story is well known, I shall only briefly recapitulate. Gamio met Boas when the latter founded the International School of American Archaeology and Ethnology in Mexico City in 1910. Franz Boas, as Guillermo de la Peña has shown, felt that Manuel Gamio was the most promising of the young Mexican scholars and invited him to do his doctoral work at Columbia ${ }^{32}$. Gamio also received support from Venustiano Carranza's government even before its final triumph over Pancho Villa, and in 1917 he created the Department of Anthropology in Mexico's agriculture and development ministry. From this position, Gamio organized a monumental study of the population of the valley of Teotihuacán.

In San Juan Teotihuacán Gamio found a perfect parable for the Mexican nation. The valley of Teotihuacán was rich, but its people were poor; the ancient city was the site of astonishing civilizational grandeur, but the current inhabitants had degenerated due to the Spanish conquest, to exploitation, and to the poor fit between Spanish culture and the racial characteristics of the Indians. Equally important, perhaps, the setting offered up the raw materials for the presentation of a national aesthetics, a strategy that had already been implemented by the authors of Mexico a través de los

31. Thus, BANCROFT, 1883 , p. 40-41, writes : « I am really astonished at the great number of pamphlets and books for the young relating to the history of this country, almanacs of history, catechisms of history, treatises on history, etc. These together with the numerous historical holidays and celebrations show as deep and demonstrative a love of country as may be found, I venture to assert, anywhere else on the globe. There is certainly nothing like it in the literature of the United States. » It is possible that Mexican obsessions with history had their roots in the civil wars, although there is certainly much influence from Spanish ideas of lineage and inheritance.

32. PeÑa, 1995, p. 279. Important sources on Gamio include González Gamio, 1987, Tenorio Trillo, 1999; Stern, 1999a and 1999b, Reyes, 1991, Buffington, 2000, and Limón, 1998, chap. II. 
siglos and the architects of Mexico's exhibit at the Paris world's fair of 1889. This work was continued by Gamio, who attempted not only to extend the use of an Indian iconography in Mexican publishing and architecture, but also to adopt an indigenizing aesthetic for the enlightened classes, and to engage with indigenous culture, bringing it to bear on modern technologies in architecture and cinema ${ }^{33}$.

[t]he elevation of traditional culture for the consumption of elite classes was a matter of some controversy and it was often the object of disdain in the Restored Republic and during the Porfiriato (it can still be controversial today) ${ }^{34}$. Gamio's involvement in the revalorization of indigenous culture was part of a long-term civilizational process for the Mexican elite.

On the other hand, unlike his Porfirian predecessors, Gamio felt that the role of the anthropologist was not only to present the past as a vision of a possible future, but also to intervene as the enlightened arm of government, as the arm of science that was best equipped to deal with the management of population and with forging social harmony and promoting civilization. Thus, for Gamio the actions of the anthropologists were the actions of the nation itself. In a prologue to a booklet that publicized international reactions to La Población del valle de Teotihuacán, Gamio explains that he brought this compendium of flattering comments to print not as an act of self-promotion, but rather because La Población... « is a collective work that has national dimensions ». Moreover,

« [t]he opinions and critical judgments not only praise the scientific methods that preside over the research comprised in this work and the social innovations and practical results that were obtained. There is also in several of the most distinguished foreign judgments the suggestion that a number of other nations follow Mexico's example in favor of the well-being and progress of their own people, a judgment that shall undoubtedly satisfy the national conscience ${ }^{35}$. »

On the other hand, the fact that Teotihuacán and the Department of Anthropology of the Secretaría de Agricultura y Fomento were both national symbols did not mean that they were equal, for whereas Teotihuacán stood for the nation due to the wealth of its territory, the grandeur of its past, and because of its racial and cultural composition (which reflected a

33. For example, for a wedding banquet in honor of the Gamio marriage, the Departamento de Antropología offered their honored guests dishes with titles such as « arroz a la tolteca », «mole de guajolote teotihuacano », «liebres de las pirámides », and «frijoles a la indiana ». Invitation to the banquest is reproduced in GonZÁLEZ GAMIO, 1987.

34. For example, when a critic of 1871 described Guillermo Prieto's poetry as versos chulisimos oliendo a guajolote (beautiful verses that smell of the indigenous term for turkey), this was taken as an insult, see the debate in Altamirano, 1871, p. 108-145.

35. GАміо, 1924, p. 2. 
400 years process of degeneration), the Department of Anthropology was the head of the nation from which the promotion of civilization was to come. This is most potently brought home in the instructions that Gamio gave his researchers before they began fieldwork in Teotihuacán:

«We then suggested to our personnel that they shed the prejudices that can arise in the minds of civilized and modern men when they come into contact with the spirit, the habits and customs of the Teotihuacanos, whose civilization has a lag of 400 years. We advised that they should follow strict scientific discipline in the course of their actions, but that they should make every effort to temporarily abandon their modes of thought, expression and sentiments in order to descend in mind and body until they molded to the backward life of the inhabitants ${ }^{36}$.»

Alexandra Stern has shown the connections that existed between the work of Gamio and other «mestizophilic » nationalists and the eugenics movement ${ }^{37}$. One aspect of this relationship that is pertinent to our discussion here is that the view of the current population as degenerate, as having been made to depart from the best developmental possibilities of its race, went along with quite a challenging and revolutionary set of policies. Indeed, as a high government official leading an official project, Gamio had an interventionist role in local society that was entirely different from that of foreign anthropologists. By his recommendation, the government raised the salary of the area's 400 government employees (mostly employed in the archaeological dig and in the various development projects that Gamio promoted) in order to nudge up the salaries that local hacendados paid their peons. Gamio had lands distributed to peasants. A new road, a railroad station, medical facilities, and schools were built.

The combined power of an integrative scientific method, embodied in anthropology, and its practical use by a revolutionary government was so dazzling that Gamio compared the mission of the Department of Anthropology with the Spanish conquest :

«We believe that if the attitude of governments continues to be of disdain and pressure against the indigenous element, as it has been in the past, their failure will be absolute and irrevocable. However, if the countries of Central and South America begin, as Mexico has already begun, a new conquest of the indigenous race, their failure shall turn into a triumphal success ${ }^{38}$.»

36. Gamio, 1924, p. 51.

37. Gamio was elected vice-president of the Second International Eugenics Congress in Washington DC in 1920, see BufFington, 2000, p. 154, and for a full discussion of Mexican eugenics, see Stern, 1999a, chap. IV and v, and 1999b.

38. Gamio, 1924, p. 49, my emphasis. 
Thus, the discontinuities between Gamio and Porfirian ethnohistorians or ethnolinguists like Alfredo Chavero or Francisco Pimentel are as interesting as their convergence : both believed in the degeneration of Mexican races after the conquest, both believed in the grandeur of Mexican antiquities; and both placed their knowledge in the service of national development. However the Porfirians did so mainly as part of an effort to present Mexico in the international arena, as a contribution to efforts to bring foreign migrants, foreign investments and tourism to Mexico, whereas Gamio took these theses and applied them not only to shaping the national image, but also to the art of governing. By doing field research, by creating his own, « integral », censuses, and by intervening in a direct and forceful manner in local reality, he could at once participate in the process of producing Mexico's image abroad and help fashion internal frontiers ${ }^{39}$. The similarities and differences between the two anthropological styles parallel the similarities and differences between the Porfirian and the Revolutionary governments : both were modernizing regimes that aimed at portraying the republic as being led by enlightened and scientific vanguards, but whereas the Porfirian regime placed its bets mostly on providing every possible convenience to foreign capital, the Revolutionary governments tried to balance their efforts to attract foreign investors and their commitment to internal social and agrarian reform. This latter formula has been seen in the 20th century as the more attractive and desirable in Mexico.

\section{CONSOLIDATION OF A NATIONAL ANTHROPOLOGY}

When the 1968 generation accused Mexican indigenistas of shaping a strictly national anthropology, Gonzalo Aguirre Beltrán, director of INAH, probably rightly accused them back of not having read the indigenistas closely $^{40}$. Aguirre Beltrán went ahead and named a number of cases of studies that had been done by Mexican anthropologists abroad; he could also have

39. The difference between these two approaches was felt to be so sharp at the time, that in the congress aimed at establishing the 1917 constitution, Porfirian cientificos were seen as dubious Mexicans, as can be witnessed from the following speech by congressman José Natividad Macías on the proposed law of nationality, see NorIEGA, 1967, p. 255 (my emphasis) : «Would any of you admit Mr. José Yves Limantour [Diaz's finance minister, born in Mexico of French descent] as a Mexican citizen by birth? Answer frankly and with your hand on your heart. (Voices : No! No!) Would you take as a Mexican by birth Oscar Braniff, Alterto Braniff, or Tomás Braniff? (Voices : No! No! We wouldn't take any científicos!) »

40. Aguirre Beltrán, 1992, p. 104. 
listed the active interest that indigenistas, beginning with manuel Gamio and Moises Saenz, showed in exporting Mexican anthropology to other locations ${ }^{41}$. Nevertheless, one can still argue that the ' 68 generation was correct on this point, for the anthropology that Mexican indigenistas exported was a national anthropology, geared to shaping connections between the ancient past, contemporary ethnic or race relations and national modernizing projects. As the Mexican government moved from the early active stages of the revolutionary period to institutional consolidation in an era of much industrial growth, the position of anthropology became at once more institutionalized and less capable of challenging the received status quo.

The period that runs roughly from 1940 to the late sixties is a time when a nationalist orthodoxy prevailed. This is also the time when most of the great state institutions that house Mexico's large professional establishment were built: the Instituto National de Antropología e Historia (INAH, 1939), the Escuela Nacional de Antropología e Historia (ENAH, 1939), the Instituto Indigenista Interamericano (1940), the Instituto Nacional Indigenista (1949), the National University's Sección de Antropología (1963), and the new Museo Nacional de Antropología (1964). The growing strength of the Mexican state and the institutional consolidation of anthropology, along with foreign (principally American) anthropologists' interest in alterity and the delicate position of American researchers in Mexico during the Cold War, are all factors that conspired to take the sting off of foreign anthropologists as harsh critics ${ }^{42}$. It is impossible to imagine the kind of candid commentary that we read in Tylor's book regarding, for instance, «what a destructive animal a Mexican soldier is », being published by a prominent United States, British or French anthropologist in this period (that has rather revealingly been labeled «the golden age » of Mexican anthropology $)^{43}$.

Instead, foreign anthropologists sought mutually beneficial collaborations or else they were as unobtrusive as possible. They worried about being able to pursue their research interests and about being able to send students to the field. Even so, the orthodoxy of Mexican official anthropology still faced an external challenge, a challenge that is endemic to the very proposition of a nationalized scientific discipline. In this period of

41. See Antonio Carlos de Souza Lima, this volume, p. 381-410.

42. The impact of the Cold War on Mexican anthropology has not yet been studied. The recent revelation that a former director of the National School of Anthropology, Gilberto López y Rivas, spied for the Soviet Union in the United States suggests that this is a significant topic. The effects of Plan Camelot on the intellectual climate in the region are better known, see Horowitz, 1974. Sullivan, 1989, is an important book on the relationship between anthropology and diplomacy in the first half of the twentieth century. On López y Rivas, see Wise, 2000, chap. XII, and Proceso, 2000a and 2000b.

43. Téllez Ortega, 1987. 
industry and progress, the challenge of foreigners was threefold: they could uncover the dark side of modernization; they could adhere to the Indian and reject the modern; or they might further the political interests of their nations at the expense of the Mexican government. I will briefly exemplify how these dangers were perceived in this period by examining two incidents.

In December of 1946, president Miguel Alemán had just taken office. Robert Redfield, professor of anthropology at the University of Chicago, and two high officials of the Mexican government (Mario Ramón Beteta and Alejandro Carrillo), were invited to discuss the president's inaugural speech on Mexican national radio. The event generally went off without a hitch, except for a newspaper article attacking Redfield's position that appeared in La Prensa Gráfica ${ }^{44}$.

After reciting Redfield's impressive scientific credentials ${ }^{45}$, Fernando Jordán focussed on a question that Redfield raised, which was whether the industrialization of Mexico would not carry with it a radical change in the mores of the Mexican people. Would industrialization not involve the standardization of indigenous cultures? Would it not diminish the beauty of a people that had well defined ethnic characteristics, a people who gave great personality to Mexico? The radio host who was interviewing Redfield responded quickly that «the traditional moral structure of the Mexican people is so strong that not even three centuries of Spanish domination were able to change it in the least ». However, Jordán reacted less defensively :

\begin{abstract}
«Mexican curios»
«If Mr. Smith, Mr. Adams, or any other tourist who had spent one month in our country had raised the same question, he would have reaffirmed the conception that we have of many of them. We would have thought him superficial and naïve. However, the question was raised by Dr. Redfield, a professional ethnologist, a renowned sociologist and author of a number of books about Mexico and its aboriginal cultures [...] It is thus impossible to believe that Redfield's question was foolish or idle. But in that case, what does it mean?

«In our view it means several things at the same time : firstly, that Mexico, for the scholar, only has a proper form when it is viewed through the kaleidescope of native costume, dance, and through the survivals of prehispanic cultures and the «folkloric » misery of indigenous people. But if this is part of Mexico, it is not Mexico itself, and it is not what our nation wishes to preserve. »
\end{abstract}

44. JORDÁN, 1946.

45. By 1946 REDFIELD had published Tepoztlán, Mexican village (1930), The Folk Culture of Yucatan (1941), and his work on peasantries, acculturation and urbanization was highly influential. 
Jordán is shocked that a famous sociologist could replicate the superficial opinions of a tourist, but he offers an explanation of Redfield's true motives :

« The ethnological laboratory »

«From another point of view, and given the trajectory of American anthropologists, Redfield's question can be interpreted in a different way. We feel that it expresses the researcher's fear of losing [...] the living laboratory that he has enjoyed since the days of Frederick Starr [another University of Chicago anthropologist]. He fears that he shall no longer be able to vivisect the Otomí, Tzotzil, Nahua, or Tarahumara cultures. He trembles at the thought of seeing the Tehuana's dress, or the "curious" rags of the Huichol, being substituted by the overall that is necessary on the shop floor or the wide pants needed in agriculture. He is expressing his ideal of stopping our nation's evolution in order to preserve the colorful misery of our Indians, a misery that will provide material for a series of books - most of which are soporiferous - in which the concept of culture will be represented by a set of isolated and static "ethnic" attributes that have no relation to the Indian's dynamism [...] »

The foreign anthropologist is interested in exoticizing Indians, in maintaining Mexico as a kind of laboratory or ecological preserve, and not in solving the country's pressing social and economic problems. As such, his opinions and research ideals should be rejected in favor of a more interventionist approach, of an approach that is committed to modernization and social improvement. Foreign interest in traditional cultures is welcome in so far as it explores the roots and the potential of the Mexican people, or in so far as it adds its efforts to the practical guidelines set by governmental projects, but when foreigners begin to value the traditional over the modern, what we have is a pernicious form of colonialism.

We should note that Jordán's own implicit program for the Indians (he had studied anthropology at the National School and favored president Alemán's modernization program) denied anthropology as Redfield understood it. The «internal colonialism » of Mexican anthropology could not uphold diversity over progress, whereas the neo-colonial American or European anthropologist could not intervene directly in Mexico, and thus had a vested interest in diversity. National anthropology and metropolitan anthropological traditions relied on one another, but they also denied each other. Thus Gamio could not be a true cultural relativist like his mentor Boas and still retain his brand of applied anthropology, and neither would Boas fully approve of the bewildering variety of applied projects that Gamio liked to juggle. As a result, the degree of mutual ignorance that is tolerated between these traditions generally, and between Mexican and American anthropologies in particular, rests on epistemological conditions that run deeper than mere patriotic rejection or language barriers. 
For example, after the publication of the Spanish language edition of Five families in 1961, Oscar Lewis remarked that:

«Some of the [Mexican] reviews [of Five families] seem excellent to me and others very negative. But even in the good ones I feel there is some resentment of the fact it was a North American, a gringo, who has acquainted the world, and even Mexicans, with a little of the misery in which so many families live. «I regret it very much if I have offended some Mexicans with my work. It was never my intention to hurt Mexico or Mexicans because I have so much affection for them [...].

« Many times I have suggested that it would be good if some Mexican anthropologists would be willing to leave their Indians for a while and come to my country to study the Neighborhoods of New York, Chicago or of the South. I have even offered assistance in getting grants for them ${ }^{46}$.»

Nevertheless, the project of Mexicans studying the United States has not yet come to fruition. The very idea of a national anthropology runs against it : what would a book by a Mexican on the United States be used for? Unless of course it were a book about Mexicans in the United States, or about American interests in Mexico. There is no public in Mexico, no institutional backing for this product, which would then be destined to be either an erudite curiosity, or worse, a Mexican anthropologist doing the Americans' job for them ${ }^{47}$. There was no possible symmetry of the sort imagined by Lewis in his well-meaning but also slightly disingenuous comment.

Thus, the threat of a scientific indictment of Mexican modernization by foreign scientists remained, and Mexican reactions to the translation of Lewis' Children of Sánchez (1964) were even more severe than to Five families. In a letter to Vera Rubin, Lewis summarized the attack that the Sociedad Mexicana de Geografía y Estadística mounted against his book :

«1. The book was obscene beyond all limits of human decency;

«2. The Sánchez family did not exist. I had made it up;

«3. The book was defamatory of Mexican institutions and of the Mexican way of life;

«4. The book was subversive and anti-revolutionary and violated article 145 of the Mexican Constitution and was, therefore, punishable with a twenty-year jail sentence because it incited to social dissolution;

«5. The Fondo de Cultura Económica, the author, and the book were all cited for action by the Geography and Statistics Society to the Mexican Attorney General's Office;

46. Oscar Lewis to Arnaldo Orfila, October 26, 1961, in Rigdon, 1988, p. 288-289.

47. Mexican studies of Mexicans in the United States have a tradition, dating back to Gamio, 1931. For a discussion of the ways in which these studies were subordinated to Mexican national interests, often at the expense of the Mexican-American perspective, see Limón, 1998, chap. II. 
«6. Oscar Lewis was an FBI spy attempting to destroy Mexican institutions $^{48}$.»

Much of the Mexican intelligentsia rallied to the cause of Oscar Lewis at this point, including some anthropologists such as Ricardo Pozas, who had been highly critical of Five families, because they saw in the Society's attack the hand of the government trying to keep all eyes off of the destructive effects of Mexican modernization, that is off of urban poverty. Nevertheless, Arnaldo Orfila, the great Argentine editor and then director of state-owned Fondo de Cultura Económica, Mexico's most prestigious publisher, was forced to resign from his post, and Lewis published the third edition of The Children of Sánchez with a private publisher.

The implications of these two cases are clear. The whole set of views that in Mexico came to be called « officialist », and which more or less served to demarcate the limits of mainstream Mexican anthropology, had a tense relationship both with anthropologists who might romanticize Indians to the degree of rejecting modernization, and with those who studied the wrong end of the acculturation process, that is, the unhappily modernized end. If the anthropologists doing the work were American, then these tendencies were all the more menacing. Moreover, the rejection of these foreign works was also a way of reigning in work done by Mexicans, work that could be seen as unpatriotic or as bookish and irrelevant ${ }^{49}$.

THE EXHAUSTION OF A NATIONAL ANTHROPOLOGY?

I began this paper by noting the sense of estrangement, of being condemned to eternal repetition, that has surfaced on occasion in recent years. The sense that anthropology in Mexico is destined to take its place inside a government office, regulating the population, writing the governor's speeches, or presenting a dignified face for the tourist. The sense that Mexican academic anthropology will always be confined to its pre-existing public, to a national public that cares only about the solution to the socalled «Great National Problems.» The uneasy feeling that nags the student of Mexican anthropology when she realizes that Francisco Pimentel was a high official in Maximilian's court, that Alfredo Chavero was the

48. Oscar Lewis to Vera Rubin, November 12, 1965, in Rigdon, 1988, p. 289.

49. This was, in fact, pretty much what the official attitude to the 1968 movement boiled down to : student unrest was giving a poor image of Mexico abroad precisely at the time when the nation was on display, at the time of the Olympic games. 
president of the Sociedad de Amigos de Porfirio Diaz, that Manuel Gamio was the founder of the Departamento de Asuntos Indígenas, under-secretary of education, and director of the Instituto Indigenista Interamericano, that Caso was founding director of INAH and ENAH, that Arturo Warman is minister of Agrarian Reform...

This atavistic sensation is, nonetheless, to some degree a false one. There is a useful corollary to Marx's $18^{\text {th }}$ Brumaire that I think can be usefully applied here, which could be something like «moins ça change, moins c'est la même chose» (the less it changes, the less it remains the same). The pattern of absorption of Mexican anthropology by the state is in some respects quite different today from the times when anthropology had a central role to play in national consolidation. The preoccupations that characterized anthropology in Mexico, even before its institutional consolidation in the late 19th century, were related to the historical origins of the nation and to the characteristics of its peoples. The study of the origins and of the attributes of the nation's « races » was especially important in Mexico, where independence preceded the formation of a bourgeois public sphere $^{50}$. At least until very recently Mexico has been a country in which public opinion is to a large degree subsidized and dramatized by the state. Anthropological stories of national origins and of racial and cultural difference were therefore useful to governments and they were routinely projected both onto the nation's internal frontiers and abroad. Anthropology has helped to reconfigure the hierarchical relations that develop between sectors of the population, and it contributed to the formation and presentation of a convincing national teleology.

The multiplication of state funded anthropological institutions in the seventies and eighties seem to respond more to the growth of the educational apparatus and to state relations with certain middle class sectors than to the need for anthropologists as technocrats. The existence of certain highly visible anthropologists in government masks the relative decline of the political significance of national anthropology for the Mexican state. Moreover, in Mexico as elsewhere, the strategies and role of the state in shaping the contours of society have been deeply transformed from the 1980s forward. The crisis in anthropology today is not so much about the discipline's absorption by the State, as it is about its uncertain role in the market-place.

In the stages that I have outlined in this paper, there is a distinct sense of exhaustion of the possibilities of the national anthropology paradigm : it began with the task of fashioning a credible national image that could do the work of harnessing the transnational machinery of progress. From there

50. Guerra, 1998, introduction and forthcoming; Escalante, 1992; Lomnitz, 2000. 
on national anthropology complemented this task with an active role in the management of the indigenous population (which in the early 20th century could mean a concern with the vast majority of the nation's rural population). This development of the anthropological function gained much prestige from the revolutionary government's capacity to distribute land and to mediate in labor and land disputes.

1968 marked a watershed for Mexican national anthropology because the student movement reflected a shift in the relative importance of Mexico's urban population. Correspondingly, the magnificos and others no longer called for absorbing Indians into the nation, but argued for a more theoretically inclined anthropology. In fact, each of the major moments of Mexican anthropology, from the cientificos to the revolutionaries, to the anthropology that blossomed after 1968 has involved a «theoretical inclination. » Each has looked to the international field for inspiration or for authority, and intellectual leaders at least have had direct connections with the most prominent leaders of the international field. The apparent paradox, however, is that once theoretical inspiration is channeled to the national anthropology model, dialogue with the international community gets reduced to conversations with area specialists at best. However, as I have shown in detail, there are causes of substance that restrict the relationship between national anthropology and its metropolitan counterparts, for the relationship between these two sorts of anthropologies has more often been one of mutual convenience than of true dialogue, since anthropologies that are devoted to national development must consistently choose modernization over cultural variation, and they must balance studies of local culture with a national narrative that shapes the institutional framework of the field.

In 1968 there was momentary awareness of the conceptual and political confinement that was embedded in "national anthropology ». However De eso que llaman antropología mexicana was still, unwittingly perhaps, a version of a national anthropology :

«Our anthropology has been indigenista in its theme. Even today it is conceived of as a specialization in particular problems. Indigenismo is atomizing and it tends to interpret its materials in an isolated fashion (en sí mismos). Indigenismo has rejected the comparative method and the global analysis of the societies in which Indians participate ${ }^{51}$.»

The final phase of Mexican national anthropology (1970s-1980s) was an expansive moment that had a number of things in common with the heady days of Gamio, for the anthropology of the seventies and early eighties had

51. WARMAN, 1970, p. 37 (my emphasis). 
to reinvent a nation that no longer had an indigenous baseline but was still centered on taking command of projects of national development. The call to develop a holistic and comparative study of «the societies in which Indians participate » was therefore just as prone to the vices of bureaucratization, theoretical sterility, parochialism, and cooptation by the state as indigenismo had been.

Today, an enlightened vanguard may no longer realistically aspire to shape public opinion for internal purposes, and discourses regarding cultural origins and social hierarchies are no longer central to the allure of the country for foreign governments and capitalists. In this context, there is a real need for invention. There may no longer be a viable way of isolating the nation as the anthropologist's principal political and intellectual object, and Mexican anthropology may have to diversify its communitarian horizons and reinvent itself.

Claudio LoMNITZ

(May 2000). 


\section{REFERENCES}

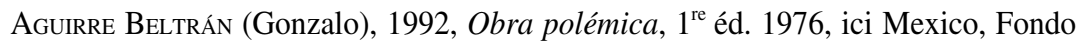
de Cultura Económica.

Altamirano (Ignacio Manuel), 1871, Diarios, Mexico, Conaculta (Obras completas, vol. XX).

Asamblea del Departamento de Querétaro, 1852, « Notas estadísticas del departamento de Querétaro, formadas por la asamblea constitucional del mismo, y remitidas al supremo gobierno... », BSMGE, t. III, p. 169-236.

Bancroft (Hubert), 1883, Observations on Mexico, manuscript, University of California-Berkeley, Bancroft Library.

Bartra (Roger), 1999, La Sangre y la tinta. Ensayos sobre la condición postmexicana, Mexico, Oceano.

BERNAL (Martin), 1987, Black Athena. The Afrocentric roots of classical civilization, New Brunswick, Rutgers University Press, vol. I.

BonfIL (Guillermo), 1970, « Del indigenismo de la revolución a la antropología crítica », in Arturo Warman, Guillermo Bonfil, Margarita Nolasco, Mercedes Olivera and Enrique Valencia, De eso que llaman antropología mexicana, Mexico, Editorial Nuestro Tiempo.

British Museum (The), 1965, Henry Christy. A pioneer of anthropology, London, The British Museum.

BSMGE = Boletin de la Sociedad Mexicana de Geografía y Estadística, Mexico, 1835 -

Buffington (Robert), 2000, Criminal and citizen in modern Mexico, Lincoln, University of Nebraska Press.

Chavero (Alfredo), 1888, Mexico a través de los siglos. Vol. I : Historia antigua de la conquista, Barcelona, Espasa y Cía.

Escalante (Fernando), 1992, Ciudadanos imaginarios, Mexico, El Colegio de México.

Estrada (Juan), 1852, «Estado libre y soberano de guerrero. Datos estadísticos de la prefectura del Centro », BSMGE, t. III, p. 71-75.

Gamio (Manuel), 1922, La Población del valle de Teotihuacán, Mexico, Secretaría de Agricultura y Fomento, 2 vol.

Gamio (M.), 1924, Opiniones y juicios sobre la obra La Población del valle de Teotihuacán, Mexico, Secretaría de Agricultura y Fomento.

Gamio (M.), 1931, The Mexican Immigrant. His life-story, Chicago, University of Chicago Press.

García Mora (Carlos), ed., 1987-1988, La Antropología en México. Panorama histórico, Mexico, Instituto Nacional de Antropología e Historia, 15 vol.

Gerbi (Antonello), 1973, The Dispute of the New World. The history of a polemic, 1750-1900, Pittsburgh, University of Pittsburgh Press.

González Gamio (Angeles), 1987, Manuel Gamio. Una lucha sin fin, Mexico, Universidad Nacional Autónoma de México. 
GuERRA (François Xavier), forthcoming, «The implosion of the Spanish American empire. Emerging statehood and collective identities », in Luis RONIGER and Tamar Herzog, ed., The Collective and the public in Latin America. Cultural identities and political order, Brighton, Sussex Academic Press.

Guerra (François Xavier) and LAMPeriere (Annick), 1998, Los Espacios públicos en Iberoamérica. Ambigüedades y problemas, siglos XVIII-XIX, Mexico, Fondo de Cultura Económica.

Horowitz (Irving Louis), 1974, The Rise and fall of project Camelot, Cambridge, MIT Press.

JoRdÁn (Fernando), 1946, «En torno a la pregunta de un antropólogo », La Prensa Gráfica, 16 de diciembre.

Lewis (Oscar), 1961, Antropología de la pobreza. Cinco familias. Mexico, Fondo de Cultura Económica (transl. of Five families. Mexican case studies in the culture of poverty, New York, Basic Books, 1959).

Lewis (O.), 1964, Los Hijos de Sánchez. Autobiografía de una familia mexicana, Mexico, Fondo de Cultura Económica (transl. of The Children of Sánchez. Autobiography of a Mexican family, New York, Random House, 1961).

Limón (José), 1998, American encounters. Greater Mexico, the United States and the erotics of culture, Boston, Beacon Press.

LomNITZ (Claudio), 1999, Modernidad indiana. Nueve ensayos sobre nación y mediación en México, Mexico, Planeta.

Lomnitz (C.), 2000, « Nationalism as a practical system. A critique of Benedict Anderson's theory of nationalism from the vantage point of Latin America », in Miguel Angel Centeno, ed., The Other Mirror, Princeton, Princeton University Press.

Marzal (Manuel), 1981, Historia de la antropología indigenista. México y Perú, Lima, Pontificia Universidad Católica del Peru.

MÉNDEZ LAvielle (Guadalupe), 1987, «La quiebra política (1965-1976) », in GARCÍA Mora, 1987, vol. II, p. 339-438.

Noriega (Raúl), ed., 1967, 50 Discursos doctrinales en el congreso constituyente de la Revolución Mexicana, 1916-1917, Mexico, Instituto de Estudios Históricos de la Revolución Mexicana.

Ortner (Sherry), 1999, «Some futures of anthropology », American Ethnologist, vol. XXVI, 4, p. 984-991.

PeÑa (Guillermo de la), 1995, « Nationals and foreigners in the history of Mexican anthropology », in James W. Fernandez and Milton B. Singer, ed., The Conditions of reciprocal understanding, Chicago, University of Chicago Center for International Studies, p. 276-303.

Pimentel (Francisco), 1860a, « Discurso sobre la importancia de la lengüística, leido por el sr. D. Francisco Pimentel al tomar asiento por primera vez en la Sociedad de Geografía y Estadística el 22 de agosto de 1861 », BSMGE, 1860 (sic), t. VII, p. 367-371.

Pimentel (F.), 1860b, «Lengua pantomímica de Oaxaca, en sesion de 19 de diciembre de 1861 , leyó el sr. socio D. Francisco Pimentel la siguiente proposicion », BSMGE, t. VIII, p. 473.

Pineda (Emilio), 1852, «Descripcion geográfica del departamento de Chiapas y soconusco », BSMGE, t. III, p. 341.

Pratt (Mary Louise), 1992, Imperial eyes. Travel writing and transculturation, New York, Routledge.

Proceso, 1995, «Culmina el enfrentamiento con Zedillo. Carlos Salinas se va a un "exilio convenido"», March 13, p. 6-7. 
Proceso, 2000a, «Los pasos de López y Rivas como "espía soviético" en Estados Unidos », by Oswaldo Zavala, April 16.

Proceso, 2000b, "Asumo mi responsabilidad y no me arrepiento", dice el ahora diputado », by Homero CAMPA, April 16.

Redfield (Robert), 1930, Tepoztlán, Mexican village, Chicago, University of Chicago Press.

Redfield (R.), 1941, The Folk Culture of Yucatán, Chicago, University of Chicago Press.

Reyes (Aurelio de los), 1991, Manuel Gamio y el cine, Mexico, Universidad Nacional Autónoma de México.

Rigdon (Susan), 1988, The Culture Facade. Art, science, and politics in the work of Oscar Lewis, Urbana, University of Illinois Press.

Riva Palacio (Vicente) and Payno (Manuel), 1870, El Libro rojo, Mexico, Diaz de León y White.

SAID (Edward), 1993, Culture and imperialism, New York, Knopf.

Sierra (Justus), ed., 1900, Mexico. Its social evolution, Mexico, J. Ballescá \& Co.

Sociedad Mexicana de Geografía y Estadística, 1852, «Estadística de Yucatán, publicase por acuerdo de la R. Sociedad de Geografía y Estadística, de 27 de enero de $1853 », B S M G E$, p. 238-339.

STERN (Alexandra), 1999a, Eugenics beyond borders. Science and medicalization in Mexico and the U.S. West, 1900-1950, PhD thesis, Chicago, Department of History, University of Chicago.

STERN (A.), 1999b, « Buildings, boundaries, and blood. Medicalization and nationbuildings on the U.S.-Mexico border, 1910-1930», Hispanic American Historical Review, vol. LXXIX, 1, p. 41-81.

Sullivan (Paul), 1989, Unfinished conversations. Mayas and foreigners between two wars, New York, Knopf.

Téllez Ortega (Javier), 1987, « La época de oro (1940-1968) », in Garciá Mora, 1987, vol. II, p. 289-341.

Tenorio Trillo (Mauricio), 1996, Mexico at the world's fairs. Crafting a modern nation, Berkeley, University of California Press.

Tenorio Trillo (M.), 1999, «Stereophonic scientific modernisms. Social science between Mexico and the United States, 1880s-1930s », Journal of American History, vol. LXXXVI, 3, p. 1156-1187.

Turner (John Kenneth), 1911, Barbarous Mexico, Chicago, C. H. Kerr and Co.

Tylor (Edward B.), 1861, Anáhuac, or Mexico and the Mexicans, ancient and modern, London, Longman, Green and Roberts.

VÁZquez LEón (Luis), 1987, «La historiografía antropológica contemporánea en México », in García Mora, 1987, vol. I, p. 176-194.

Warman (Arturo), 1970, « Todos santos, todos difuntos », in Arturo Warman, Guillermo Bonfil, Margarita Nolasco, Mercedes Olivera and Enrique Valencia, De eso que llaman antropología mexicana, Mexico, Editorial Nuestro Tiempo.

Widdifield (Stacie G.), 1996, The Embodiment of the national in late nineteenthcentury Mexican painting, Tucson, University of Arizona Press.

Wise (David), 2000, Cassidy's run. The secret spy war over nerve gas, New York, Random House. 